УДК $37.026 .6+7.092$

DOI https://doi.org/10.32843/2663-

6085/2021/33-1.9

\section{Гаценко Г.С.}

заслужений працівник культури України, старший викладач

кафедри музичного мистецтва

ПВНЗ «Київський університет культури»
У статті окреслено роль змагань для фрормування співацької майстерності. Визначено їх мотиваційний характер. Підкреслено той фрактор, що різні фрорми вокальних змагань існували від зародження музичного мистецтва. Їх модифрікування може розглядатися як закономірний процес. Динаміка змін форм вокальної змагальності може бути представлена як результат розвитку потреб виконавців та запитів слухачів. Таку роль виконували вокальні змагання, конкурси, фестивалі, а тепер і вокальні шоу. Актуальність вокальних шоу та інтерес до них з боку широкого загалу роблять їх набагато більш перспективними для співаків. Хоча оцінювання на професійних конкурсах може бути набагато більш якісним, воно має менш ціннісний характер для молодих виконавців. Участь у вокальних шоу є цікавим та корисним досвідом, який дає можливість оцінити якість власної підготовки. Підкреслено, що під час підготовки до змагань співаки здійснюють аналіз виступів інших вокалістів. Результати аналітичної діяльності можуть допомогти звернути увагу на певні недоліки, які можуть бути пов'язані з внутрішніми чинниками, а саме відсутністю впевненості, неготовністю виступати перед незнайомою аудиторією, надмірним хвилюванням, недостатнім рівнем акторської чи вокальної майстерності. Позитивним чинником участі у розважальних програмах $\epsilon$ здатність встановити зв'язки з представниками шоу-бізнесу, мати змогу осягнути усі етапи, які наявні у творчій просресійній діяльності співаків. Педагоги з вокалу мають враховувати зацікавленість молоді та готувати студентів до участі не лише в академізованих формах оцінки рівня співацької майстерності, але й у вокально-розважальних формах змагальності. Таким чином, з використанням мотивації студентів можна досягнути кращих результатів. Визначено, що основна мета усіх шоу пов'язана з розвагою публіки та комерційною успішністю каналів, проте вони впливають на розвиток суспільного смаку, фрормують стандарти виконавської практики та сприяють еволючіонуванню естрадної культури України. Ключові слова: вокальні змагання, вокальні шоу, співак, педагог, оцінювання, майстерність, творчість, мотивація.
The role of competitions for the formation of singing skills is outlined. Their motivational character is determined. The fact that various forms of vocal competitions have existed since the birth of musical art is emphasized. Their modification can be considered as a natural process. The dynamics of changes in the forms of vocal competition can be presented as a result of the development of the needs of performers and listeners' requests. Such a role was played by vocal competitions, contests, festivals, and now vocal shows. The relevance of vocal shows and interest in them from the general public make them more promising for singers. Although evaluation in professional competitions can be much better, it is less valuable for young performers. Participation in vocal shows is an interesting and useful experience that provides an opportunity to assess the quality of their own training. It is emphasized that in preparation for the competition, the singers analyze the performances of other vocalists. The results of analytical activities can help to draw attention to certain shortcomings that may be related to internal factors - lack of confidence, unwillingness to perform in front of an unfamiliar audience, excessive excitement, and lack of acting or vocal skills. A positive factor in participating in entertainment programs is the ability to establish links with representatives of show business, to be able to understand all the stages that are present in the creative professional activities of singers. Vocal teachers should take into account the interest of young people and prepare students to participate not only in academic forms of assessing the level of singing skills, but also in vocal and entertaining forms of competition. Thus, using the motivation of students, you can achieve better results. It is determined that the main purpose of all shows is related to the entertainment of the public and the commercial success of the channels, but they influence the development of public taste, form standards of performing practice and contribute to the evolution of Ukrainian pop culture.

Key words: vocal competitions, vocal shows, singer, teacher, assessment, skill, creativity, motivation.
Постановка проблеми у загальному вигляді. Естрадна музика сьогодення $є$ ссрерою, що демонструє активний розвиток. Формування різних стилів, поява нових виконавців $є$ ознаками того, що цей напрям культури є затребуваним і таким, що відкритий до інновацій. Існує низка навчальних закладів різних освітніх рівнів (від шкіл і студій до університетів та консерваторій), у яких здійснюється підготовка естрадних та джазових вокалістів. Проте існування цих інституцій та їх плідна робота не є запорукою того, що виконавець після отримання кваліфікаційного рівня зможе реалі- зувати себе на професійному рівні. Надзвичайно важливою $є$ виконавська практика, яка має здійснюватися паралельно 3 навчанням та унаочнювати нагальні проблеми, які виникають у процесі здобуття співаком професійного рівня. Одним із чинників, що може впливати на самореалізацію естрадних співаків, є участь у вокальних шоу.

Аналіз останніх досліджень і публікацій. Протягом останніх років сорормувався стійкий інтерес до питання розвитку сорери шоу-бізнесу, що досліджується як самостійне та цілісне явище. Зацікавленість цією проблематикою спостерігається 
у роботах Н. Донченко, В. Мойсеєнка, які досліджують сучасні видовищно-розважальні естрадні шоу на естраді в аспекті розвідок особливостей їх режисури. М. Дружинець розглядає вітчизняні вокальні телевізійні талант-шоу, а також пісенний конкурс «Євробачення» як фрактор європеїзації та євроінтеграції. Значення культурно-мистецьких проєктів для розвитку естрадного вокалу є предметом наукового інтересу Н. Регеші, О. Тринько, Н. Ковмір. Основні тенденції розвитку вокальних фестивалів-конкурсів у сучасному українському просторі окреслює у своїй статті Н. Овсяннікова. Педагогічні аспекти участі у вокальних конкурсах, змаганнях та інших проєктах ґрунтовно викладені у дисертаційному дослідженні Н. Овчаренко.

Виділення не вирішених раніше частин загальної проблеми. Виникнення нових фрорм, у яких розкривається творча активність співаків, має бути розглянуте як невід'ємна частина підготовки до профресійної реалізації виконавця. Однак це питання досі не привертало увагу фрахівців у сорері вокальної педагогіки.

Мета статті полягає у дослідженні ролі вокальних шоу у розвитку співацької майстерності.

Виклад основного матеріалу. Велику роль у розвитку студентів, які навчаються у вищих навчальних закладах мистецького спрямування, має оцінювання рівня їх творчих досягнень. Якщо у теоретичних дисциплінах процес моніторингу якості освіти та рівня засвоєння матеріалу здійснюється шляхом тестувань, теоретичних заліків, письмових та усних екзаменів, то оцінка студента-виконавця можлива лише через практичні фрорми. Такі вкрай різні випробування, як різноманітні музичні змагання, виникли фрактично одночасно з появою самого мистецтва. У міфологічних уявленнях стародавніх цивілізацій було закарбовано історії, пов'язані зі змаганнями співаків, музикантів-інструменталістів, силою впливу їх майстерності на оточуючих. В них передавалось опоетизоване ставлення до музики, виконавців. Змагальність була закладена у багатьох творах доби бароко. Доволі частим явищем було намагання позмагатись у майстерності та віртуозності не лише між співаками, але й між співаками та інструментами оркестру. В хід ішли такі засоби, як виконання надскладних пасажів, охоплення крайніх точок регістру, технічна вправність співу різноманітних мелізмів. Водночас розвиток вокальних шкіл та профресіоналізація діяльності музикантів сприяли фрормуванню сталої практики організації вокальних змагань, а згодом і конкурсів. Нині існує чимало конкурсів, що проходять у різних формах, як очній, так і дистанційній, охоплюючи як академічний, так і естрадний та джазовий спів. Н. Овчаренко відзначає велике значення участі у конкурсній та концертній діяльності як фрактору, що вплине на зростання мотивації студентів-вока- лістів. «Проведення творчих позаурочних занять із хоровим колективом, вокальним ансамблем, солістами-вокалістами, а також підготовка до концертних виступів і самі сценічні виступи сприяють формуванню мотивації учнів до занять вокальновиконавською діяльністю, особливо якщо використовуються цікавий високохудожній репертуар за вибраною манерою співу, сучасні наочні матеріали, звукопідсилююча апаратура» [4, с. 85].

Подібно до конкурсних фрорм сучасні вокальні шоу $є$ такими, хоча й мають тимчасову природу, проте їх значення для розвитку співаків неможливо переоцінити. Причому підготовка до участі має розпочинатися 3 ознайомлення 3 різними форматами в ролі спостерігачів. Не останню роль має відігравати викладач, який буде виступати у ролі організатора та ідейного натхненника. Н. Овчаренко наголошує на розширенні фрункцій викладача та аспектах його професійної справи. «Необхідним компонентом його діяльності є здатність до організаційної роботи та просвітництва, що передбачає відвідування концертів, оперних та музично-драматичних спектаклів; участь у фестивалях, конкурсах, творчих проєктах; організацію зустрічі зі співаками, творчими колективами тощо» $[4$, с. 90].

Можна виділити декілька чинників, що притаманні вокальним шоу. Участь у них є можливістю здійснити моніторинг того, яким є рівень учасників, порівняти їх можливості, надати поштовх для подальшого розвитку. В процесі участі у вокальному шоу, розрахованому на молодих виконавців, мало знаних широкій слухацькій аудиторії, таких як «Голос країни», співаки отримують нагоду продемонструвати свій творчий потенціал та розвинути його. «Закладаються досить високі стандарти вокального мистецтва, адже зазвичай увагу суддів привертають як виконавці надзвичайно обдаровані $з$ огляду на специфіку голосового апарату (мається на увазі великий діапазон, охоплення високої теситури, приємне тембральне забарвлення), так і ті, хто здатний представити у цікавій манері незвичну інтерпретацію шлягеру» [5, с. 78]. За рахунок того, що вибір суддями учасників спочатку відбувається всліпу, відкидаються усі чинники, що не стосуються вокальних здібностей. Оцінюються насамперед мистецтво співу, сила голосу, інтонаційна правильність, здатність емоційно зачепити аудиторію, тому створюється можливість не відволікатись на інші чинники, такі як зовнішній вигляд виконавця, його вміння триматись перед аудиторією, пластика та акторська гра. Це створює рівні умови для усіх, хто претендує на участь у шоу. «Головна відмінність проєкту полягає в тому, що участь у шоу забезпечують насамперед вокальні здібності та талант; зовнішність і вік учасників мають вторинне значення» [2, с. 284]. 
Для учасників, які вже обрані до подальшої участі у шоу, відкриваються надзвичайні можливості для розвитку та відточування тих аспектів, які ще необхідно доробляти. За рахунок того, що судді таких шоу $є$ професійними співаками, що мають різні погляди на виконавську практику, відбувається обмін досвідом, який сприяє кращому усвідомленню тих теоретичних засад, що викладаються у вищих навчальних закладах мистецького спрямування. Під час підготовки номерів учасники контактують з викладачами з вокалу, режисерамипостановниками, сценаристами, костюмерами, отримуючи реальний досвід участі у культурномистецькій сфері, не маючи певних поблажок чи послаблень. На відміну від професійної арт-сцени, де кожна помилка професійного виконавця може мати нищівний характер для його подальшої кар'єри, молодим учасникам шоу певні недоліки можуть пробачатися глядацькою та слухацькою аудиторію. Основним посилом подібних проєктів $€$ акцент на розвитку виконавця, його багатовимірному розкритті у різних творчих амплуа та сприянні профресійному зростанню. «Під час проєкту тренери не змінюють учасника, не обмежують його «фрорматом». Їх головна мета полягає в тому, щоби за допомогою профресійної команди підкреслити талант співака та вивести його на «музичну Говерлу» країни» [2, с. 284].

Отже, молоді виконавці, які навіть не пройшли відбір до шоу (спочатку беруть участь 5000 співаків, 3 яких обирають 150 найкращих, що вже зможуть продемонструвати свої можливості професійним «тренерам» -зіркам), отримують досвід оцінки власних здібностей. Це дає змогу скорегувати у подальшому вектор їх розвитку, звернути увагу на певні недоліки, які можуть бути пов'язані 3 внутрішніми чинниками, а саме відсутністю впевненості, неготовністю виступати перед незнайомою аудиторією, надмірним хвилюванням, недостатнім рівнем акторської чи вокальної майстерності, тобто і як фрактором оцінки власних можливостей, і як «трампліном» для подальшої творчої діяльності, і як способом презентувати себе у телемедійному просторі вокальні шоу мають бути присутні у процесі становлення молодих співаків. «Реалізація творчо-виконавського компоненту передбачає усвідомлення значення вокального виконавства та сорормованість інтересу до нього; набуття вокально-виконавської майстерності у власній сценічній діяльності» [4, с. 224].

Варто, звісно, підкреслити, що існує значна відмінність між участю у конкурсі та вокальному шоу, адже шоу-програми будуються за принципами драматургії, перетворюючись часом зі змагань на сюжетні «вистави», адже сценаристи та режисери мають зробити їх своєрідними серіалами, які б передивлялись глядачами від початку до завершення. Це обумовлює появу таких рис, як «високе емоційне напруження, ритмічна контрастність розвитку дії, виразне розкриття характеру персонажів» [1, с. 112]. Таким чином, вокально-розважальне шоу включає чимало елементів, що мало стосуються самого виконавства, натомість додають напруження й драматизму кожному випуску. Тут музичний компонент презентується в контексті «історії» виконавця, що створює менш об'єктивне сприйняття його виступів, особливо з боку телеглядачів та публіки у залі. Натомість під час участі у професійних вокальних конкурсах звертається увага передусім саме на артистизм співака, художній рівень його виконання, які оцінюються 3 урахуванням більш чітких критеріїв профресійним журі. 3 огляду на особливості розвитку сучасного виконавства для молодих співаків набагато більше мотивації викликає підготовка до участі у вокальному змаганні, ніж у вокальному професійному конкурсі, тому цей чинник має враховуватись викладачами, адже під час орієнтації студента до участі не лише в академізованих формах оцінювання їх рівня, але й у вокально-розважальних формах змагальності можна досягнути більшої зацікавленості студента та кращих результатів.

Н. Овсяннікова відзначає, що нині здійснюється активний розвиток шоу-програм, які дають змогу реалізувати свій творчий потенціал вокалістам. «Культурний простір нашої держави постійно збагачується новими яскравими проєктами (фестивалями, конкурсами, талант-шоу). Завдяки подібним заходам український шоу-бізнес поповнюється молодими, талановитими зірками. Багато молоді бере участь у таких культурних проєктах в Україні. Це дає можливість розвивати та пропагувати всі напрями естрадної культури, зокрема пісенний жанр» [3, с. 438]. Завдяки вокальному шоу «Голос країни» стали відомими такі виконавці, як Павло Табаков, солістка гурту "KAZKA" Олександра Зарицька, LAUD, CONSTANTINE, Андрій Лучанко, Марія Яремчук, TAYANNA, Христина Соловій, Андрій Хайат. Безперечно, їх особисті здібності та таланти мали значну роль у їх подальшому професійному успіху, причому багато хто з них уже мав за плечима навчання на спеціальності «Естрадний та джазовий спів» у вітчизняних навчальних закладах мистецького спрямування. Проте участь у вокальному шоу стала важливим етапом для їх просування у сфері шоу-бізнесу. Навіть відкидаючи те, що основна мета усіх шоу пов'язана з розвагою публіки та комерційною успішністю каналів, які мають боротися за рейтинги, зазначаємо, що вони впливають на розвиток суспільного смаку, формують стандарти виконавської практики та сприяють еволюціонуванню естрадної культури України.

Висновки. Змагання та конкурси співаків історично є невід'ємною частиною музичної культури. Вони дають змогу розкрити творчий потенціал співаків, виявити наявні проблеми та можливі шляхи 
їх вирішення. Участь у різноманітних шоу нині виступає важливим етапом на шляху до становлення просресійного рівня співака. Використання цієї фрорми можна розглядати як чинник, що підвищує мотивацію студентів-вокалістів. Доречним вважається дослідження шоу-програм, орієнтованих на змагальність, як джерела інорормації про запити та інтереси слухацької аудиторії.

Дослідження різноманітних чинників, які сприяють розвитку мотивації студентів-вокалістів у процесі опанування ними фраху, сприяє удосконаленню фрорм навчання та відповідності навчальних програм інтересам стейкхолдерів.

\section{БІБЛІОГРАФІЧНИЙ СПИСОК:}

1. Донченко Н., Мойсеєнко В. Сучасні видовищно-розважальні шоу на естраді: діапазон жанрів та особливості режисури. Вісник Національної акаде- мії керівних кадрів культури і мистецтв. 2017. № 1. C. 109-113.

2. Дружинець М. Пісенний конкурс Євробачення та вокальні телевізійні талант-шоу як фактор європеїзації та євроінтеграції української культури. Мuстецтвознавчі записки. 2019. Т. 35. С. 280-287.

3. Овсяннікова Н. Основні тенденції розвитку вокальних фрестивалів-конкурсів у сучасній Україні. Мистецтвознавчі записки. 2018. Вип. 33. С. 435-441.

4. Овчаренко Н. Теоретико-методологічні засади профресійної підготовки майбутніх учителів музичного мистецтва до вокально-педагогічної діяльності : дис. ... докт. пед. наук : спец. 13.00.04 «Теорія і методика професійної освіти» ; Криворізький педагогічний інститут Державного вищого навчального закладу «Криворізький національний університет». Кривий Ріг, 2016. 547 с.

5. Регеша Н., Тринько О., Ковмір Н. Роль та значення культурно-мистецьких проєктів для розвитку естрадного вокалу. Молодий вчений. 2017. № 8 (48). С. 76-79. 